Original Article

\title{
INHIBITORY ACTIVITIES OF CAMELLIA MISTLETOE (K. JAPONICA) EXTRACTS ON PANCREATIC LIPASE, TYROSINASE AND CANCER CELL PROLIFERATION
}

\author{
MIN YOUNG KIM \\ Toxicology Laboratory, Faculty of Biotechnology (Biomaterials), College of Applied Life Science, SARI, Jeju National University, Jeju, \\ Republic of Korea \\ Email: jeffmkim@jejunu.ac.kr
}

Received: 13 Jul 2017 Revised and Accepted: 31 Aug 2017

\begin{abstract}
Objective: The objective of this study was undertaken to examine pancreatic lipase and tyrosinase inhibitory activities of Camellia mistletoe (Korthalsella japonica) extracts and conduct their antiproliferative activity on several human cancer (Hela, A375, HCT 116, HepG2 and A549) and
\end{abstract} normal cells (TK6) lines.

Methods: The lipase inhibitory activity of acts of Camellia mistletoe extracts were determined from the hydrolytic reaction of p-nitrophenyl butyrate with pancreatic lipase and cytotoxicity against human cancer and normal cell lines were also evaluated using the MTT assay. The in vitro tyrosinase inhibitor potency of Camellia mistletoe extracts was estimated using mushroom tyrosinase.

Results: Both methanol and ethanol extracts of Camellia mistletoe exhibited an inhibitory effect on lipase inhibition activity with IC $\mathrm{C}_{50}$ values of 0.39 and $0.49 \mathrm{mg} / \mathrm{ml}$, respectively. Moreover, Camellia mistletoe extracts were judged to be strongly active against the cancer cell lines, while they had no antiproliferative activity against the normal human cell lines. However, they had little inhibitory effects on tyrosinase activity.

Conclusion: Camellia mistletoe extracts could be the good sources of natural lipase inhibition and anticancer agents with a great potential to be used in food and therapeutic fields.

Keywords: Camellia mistletoe, Pancreatic lipase inhibitory activity, Tyrosinase inhibitory activity, Antiproliferative activity

(C) 2017 The Authors. Published by Innovare Academic Sciences Pvt Ltd. This is an open-access article under the CC BY license (http://creativecommons.org/licenses/by/4.0/) DOI: http://dx.doi.org/10.22159/ijpps.2017v9i10.21304

\section{INTRODUCTION}

Medicinal plants are an important therapeutic aid for various ailments. In recent times, focus on plant research has increased all over the world and a large body of evidence has collected to show immense potential of medicinal plants used in various traditional systems [1]. Plants are a rich source of medicines because they produce a wide array of bioactive molecules, most of which probably evolved as a chemical defence against predation or infection. The increasing use of plant extracts in the food, cosmetic and pharmaceutical industries suggests that in order to find active compounds, a systematic study of medicinal plants is very important. Compounds from medicinal plants in the food and cosmetics industry have a central role and have a wide range of applications.

Mistletoes are native to Asia, Africa, Europe and Australia, and 70-100 species have been recorded [2]. Mistletoe extracts are used for the treatment of many diseases such as cancer, hypertension, and diabetes [3-5]. Camellia mistletoe, Korthalsella japonica (family Santalaceae), is a semiparasitic plant which is distributed in Jeju Island, Korea. Recently there has been considerable interest in the antioxidant potential and antimicrobial activities of Camellia mistletoe extracts [6, 7]. Although a lot of work was carried out with regard to the phytochemical and pharmacological evaluation of European mistletoe, Viscum album L. [8], but little is known of actual physiological benefits of Camellia mistletoe, K. japonica. Therefore, the present study was aimed to evaluate inhibitory activities of lipase, tyrosinase and cancer cell proliferation by the methanol and ethanol extracts from Camellia mistletoe.

\section{MATERIALS AND METHODS}

\section{Chemicals and reagents}

Porcine pancreatic lipase, p-nitrophenyl butyrate (p-NPB), mushroom tyrosinase, tyrosine, ascorbic acid were purchased from Sigma-Aldrich Chemical Company (St. Louis, MO, USA). Cell culture reagents were obtained from Lonza (Walkersville, MD, USA). MTT (3-[4,5dimethylthiazol-2-yl]-2,5-diphenyl tetrazolium bromide) cell proli- feration kit was purchased from Boehringer Mannheim (Indianapolis, IN, USA). All ingredients used in this study were of analytical grade.

\section{Plant material and extraction procedure}

Camellia mistletoe (K. japonica) samples were collected during May 2015 from Camellia Hill located in Andeok-myeon, Seogwipo-si, Jejudo Province, South Korea and the voucher specimens (KHUP-0803) have been deposited in the herbarium of College of Applied Life Science, Jeju National University. Samples were prepared using a previously described protocol [7]. The dried and powdered plant material $(20 \mathrm{~g})$ was extracted with $100 \mathrm{ml}$ of $100 \%$ methanol or $70 \%$ ethanol for $72 \mathrm{~h}$ and filtered, concentrated using a rotary evaporator (Buchi Rotavapor R-200, New Castle, DE, US), freeze-dried and stored at-20 USyin storage vials for experimental use. The average extraction yields (fresh sample/methanol or ethanol) were 7.1 and $10.4 \%$, respectively. Dried extracts were reconstituted in dimethyl sulfoxide (DMSO, Amresco, Solon, Ohio, USA). DMSO acts as a solvent without changing any property of the methanol and ethanol extracts.

\section{Pancreatic lipase inhibitory activity}

The lipase inhibitory activity of Camellia mistletoe extracts was estimated from the ability to inhibit the in vitro porcine pancreatic lipase activity as previously described [9] with slight modifications. The reaction mixture consisted of $6 \mu \mathrm{L}$ of $10 \mathrm{mg} / \mathrm{ml}$ of porcine pancreatic lipase and $170 \mu \mathrm{L}$ of Tris buffer. Then $20 \mu \mathrm{L}$ of Camellia mistletoe extracts was added and incubated at $37^{\circ} 7$ for 15 min. Four microliters of $10 \mathrm{~m}$ Mp-NPB was then added and incubated at $37^{\circ} \mathrm{t}$ for $60 \mathrm{~min}$.

Lipase activity was determined by measuring the hydrolysis of p-NPB to p-nitrophenol at $400 \mathrm{~nm}$ using a Spectra MR microplate reader (Dynex Technologies, Inc., Chantilly, VA, US). IC 50 , the concentration of a tested compound giving $50 \%$ inhibition of the enzyme activity, was evaluated from the least square regression line of the plot of the logarithm of concentration vs. the inhibitory activity. Hesperidin was used as the positive control [10]. 


\section{Tyrosinase inhibitory activity}

Tyrosinase inhibitory activity of Camellia mistletoe extracts was carried out by a previously described method [11] with some modifications. Briefly, mushroom tyrosinase ( $40 \mu \mathrm{l}, 110 \mathrm{unit} / \mathrm{ml})$ was mixed with $100 \mu \mathrm{l}$ of phosphate buffer $(0.175 \mathrm{M}, \mathrm{pH} 6.8)$ and $40 \mu \mathrm{l}$ of $10 \mathrm{mmol}$ tyrosine and $20 \mu \mathrm{l}$ of different concentrated Camellia mistletoe extracts $(0.125,0.25$ and $0.5 \mathrm{mg} / \mathrm{ml})$. The mixture was then incubated for $15 \mathrm{~min}$ at room temperature. Following incubation, absorbance of the mixture was determined at $475 \mathrm{~nm}$ by using a Spectra MR microplate reader. The concentration of the extract which caused a half maximal inhibition of the lipase activity $\left(\mathrm{IC}_{50}\right)$ was obtained from a semilog plot of Camellia mistletoe extract concentrations against the percentage of enzyme inhibition. Ascorbic acid $(500 \mu \mathrm{g} / \mathrm{ml})$ as positive control was used for assay.

\section{In vitro cytotoxic activity}

The in vitro cytotoxic activity of Camellia mistletoe extracts was determined from the mitochondrial activity of cell lines which represent the number of viable cells after the treatment, by using the 3-(4,5-dimethylthiazol-2-yl)-2,5-diphenyl tetrazolium bromide (MTT) cytotoxic assay on six different human cell lines in tissue culture. The human lymphoblastoid cells (TK6), cervical cancer (Hela), malignant melanoma (A375), colon cancer (HCT 116), liver cancer (HepG2) and non-small cell lung adenocarcinoma(A549) cell lines were kindly provided by Professor Wogan (Massachusetts Institute of Technology, MA, US). Hela and A375 cells were cultured in Dulbecco's modified Eagle's Medium(DMEM) supplemented with $10 \%$ heat-inactivated fetal bovine serum, 100 units $/ \mathrm{ml}$ penicillin, $100 \mu \mathrm{g} / \mathrm{ml}$ streptomycin and 2 mmol L-glutamine at $37{ }^{\circ} \mathrm{C}$ with $5 \% \mathrm{CO}_{2}$ in a humidified atmosphere. TK6, HCT 116, HepG2 and A549 cell lines were maintained in RPMI 1640, McCoy's 5A, MEM and Ham's F-12 media supplemented as above with L-glutamine, antibiotics and FBS, respectively.

The inhibitory effect of Camellia mistletoe extracts on the proliferation of human normal and cancer cells was determined using 3-(4,5-dimethylthiazol-2-yl)-2,5-diphenyltetrazolium bromide (MTT) assay. Briefly, cell suspensions $\left(5 \times 10^{3}\right.$ per well $)$ were loaded into 96-well culture plates and treated with fresh medium containing various concentrations $(0-200 \mu \mathrm{M})$ of each extract for 72 h. Cells were washed once with phosphate buffered saline and reacted with the MTT solution at $37{ }^{\circ} \mathrm{C}$ for $4 \mathrm{~h}$ to produce the formazan salt. Finally, the formazan salt formed ineach cultured cells was dissolved in DMSO, and theoptical density (OD) value of each solution was measured at $540 \mathrm{~nm}$ using a Spectra MR microplate reader. The $O D$ value detected for the control (cells without treatment with any samples) from the treated cells was plotted on the $x$-axis, designated as proliferation (\% of control), to demonstrate the effect of each sample on the viability of the related cells. The concentration of the extract which caused a half-maximal inhibition of cell proliferation $\left(\mathrm{IC}_{50}\right)$, as determined by the MTT assay, was obtained from a semi-log plot of Camellia mistletoe extract concentrations against the percentage of cell survival.

\section{Statistical analysis}

Data were analyzed using SPSS statistical software (SPSS, ver. 12.0; SPSS Inc., Chicago, IL, US). Comparisons of all results between methanol and ethanol extracts of Camellia mistletoe were made by using a non-parametric test (Mann-Whitney $\mathrm{U}$ test) with $p<0.05$.

\section{RESULTS AND DISCUSSION}

\section{Lipase inhibitory activity}

Obesity is now recognized as a major risk factor in the metabolic syndrome, diabetes mellitus, hypertension and some cancers [12]. Obesity is considered an extremely costly health problem which in developed nations accounts for $2-6 \%$ of total health care costs [13]. Currently Orlistat, a potent competitive inhibitor of gastric and pancreatic lipase, has been approved by FDA and is available as an antiobesity drug [14]. However, this medication is associated with incidence of side-effect including intestinal flatulence, borborygmi and abdominal cramps [15]. Therefore, new approaches for the treatment of obesity tried to reduce energy intake through gastrointestinal mechanisms, without altering any vital mechanisms [16]. In our current study, methanol and ethanol extracts of Camellia mistletoeinhibited the lipase activity in a dose-dependent manner in the assay system with pNPB as a substrate (table 1). With respect to the lipase inhibition, the methanol extract showed more effective activity than ethanol extract $(p<0.05)$. Nevertheless, this was weak ( $\mathrm{IC}_{50}$ value of $0.39 \mathrm{mg} / \mathrm{ml}$ ), compared to that for the positive control of hesperidin $\mathrm{IC}_{50}$ value of $0.032 \mathrm{mg} / \mathrm{ml}$ ). However, the pancreatic lipase inhibitory effect of Camellia mistletoe was superior to those when various dietary plants were screened by Kim et al. [17] and Conforti et al. [18].

\section{Tyrosinase inhibitory activity}

Tyrosinase inhibitor has been used frequently in cosmetics and depigmenting agents for hyperpigmentation. It catalyzes two different reactions using molecular oxygen the ortho-hydroxylation of tyrosine (mono-phenols) named monophenolase activity and the oxidation of 3,4Dihydroxyphenylalanine (DOPA) to dopaquinine (o-quinones) named diphenolase activity [19]. A large number of moderate to potent tyrosinase inhibitors from natural and synthetic resources have been reported during the last decade $[20,21]$. However, some tyrosinase inhibitors are considered to be cytotoxic to melanocytes and potentially mutagenic to mammalian cells $[21,22]$. Therefore, it remains necessary to search for new tyrosinase inhibitors without side effects. In this study, we found that Camellia mistletoe extracts fraction had a small inhibitory effect at the highest dose tested (table 1). However the inhibitory effect is small and it is not economically feasible to be developed further. Ascorbic acid, used as a positive control, reduced mushroom tyrosinase drastically even at the lowest dose used. Although the results of this work are inconsistent with those reported by Lee et al. [23] in that high tyrosinase inhibitory activity was detected from hot water $(64 \%)$ and ethanol (63\%) extracts of mistletoe (Viscum album) at the concentration of $100 \mathrm{mg} / \mathrm{ml}$, our study was conducted with different extraction methods, different species ( $K$. japonica) and relatively very low test concentrations $(0.125,0.25$ and $0.5 \mathrm{mg} / \mathrm{ml})$.

Table 1: Effects of the methanol and ethanol extracts from Camellia mistletoe (K. japonica) on lipase and tyrosinase inhibitory activities

\begin{tabular}{|c|c|c|c|c|}
\hline & Solvent & $\begin{array}{l}\text { Concentration } \\
(\mathrm{mg} / \mathrm{ml})\end{array}$ & $\begin{array}{l}\text { Inhibition } \\
\text { (\%) }\end{array}$ & $\begin{array}{l}\text { IC }_{50} \text { value } \\
(\mathrm{mg} / \mathrm{ml})\end{array}$ \\
\hline \multirow{4}{*}{ Lipase inhibitory activity } & $100 \% \mathrm{MeOH}$ & 0.125 & $40.1 \pm 0.15 \mathrm{M}$ & $0.39 \pm .395 \mathrm{MeOH}$ \\
\hline & & 0.25 & $41.9 \pm 1.95 \mathrm{M}$ & \\
\hline & & 0.5 & $53.3 \pm 3.3 \mathrm{se}$ & \\
\hline & $70 \% \mathrm{EtOH}$ & 0.125 & $14.9 \pm 4.95 t$ & 0.49 tOHnhibi \\
\hline \multirow{8}{*}{ Tyrosinase inhibitory activity } & & 0.25 & $25.9 \pm 5.9 \mathrm{t}$ & \\
\hline & & 0.5 & 50.5 tOHnhi & \\
\hline & $100 \% \mathrm{MeOH}$ & 0.125 & $10.8 \pm 0.85 \mathrm{M}$ & $1.40 \pm .405 \mathrm{MeO}$ \\
\hline & & 0.25 & $16.6 \pm 6.65 \mathrm{M}$ & \\
\hline & & 0.5 & $17.8 \pm 7.8 \mathrm{ib}$ & \\
\hline & $70 \% \mathrm{EtOH}$ & 0.125 & $7.3 \pm .325 t$ & 1.56 tOHory \\
\hline & & 0.25 & $12.1 \pm 2.1 \mathrm{t}$ & \\
\hline & & 0.5 & 16.0 tOHory & \\
\hline
\end{tabular}

Each values is expressed as mean \pm standard deviation $(n=3),{ }^{*} p<0.05$ compared to ethanol extract of Camellia mistletoe. 
A)

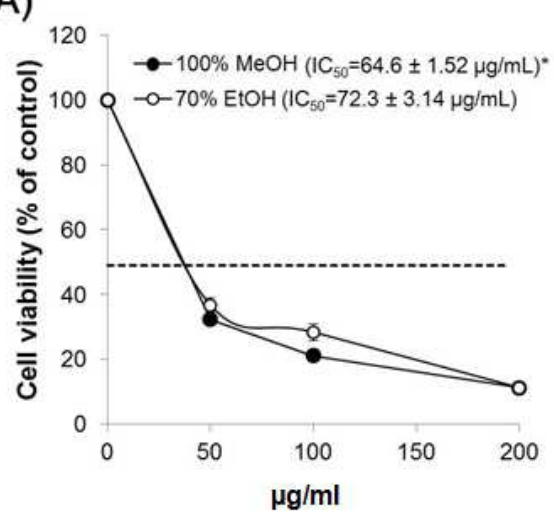

B)

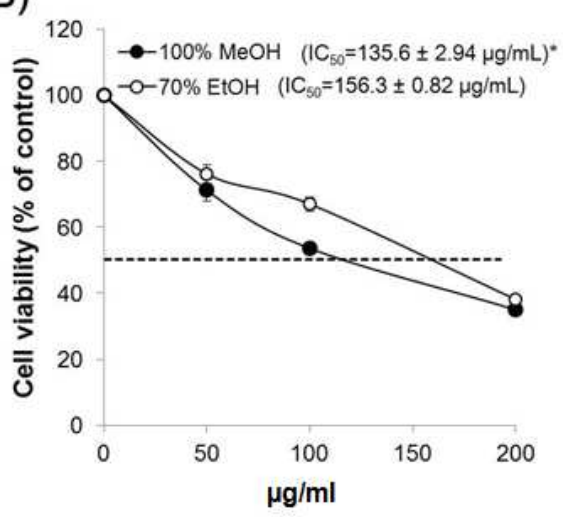

Fig. 1: The percentage of viable Hela and A375 cells after Camellia mistletoe (K. japonica) treatment, Cell extracts for $72 \mathrm{~h}$. Each point is the mean \pm SD of three experiments, ${ }^{*} p<0.05$ compared to ethanol extract of Camellia mistletoe, Cell viability was determined by MTT assay after treatment with $0,50,100$ and $200 \mu \mathrm{g} / \mathrm{ml}$ of methanol and ethanol

\section{In vitro cytotoxic activity}

Because of serious side effects and toxicity of chemotherapeutic anticancer agents, many cancer patients seek alternative and/or complementary methods of treatment. Plants have been used for treating various diseases of human beings and animals since time

\section{A)}

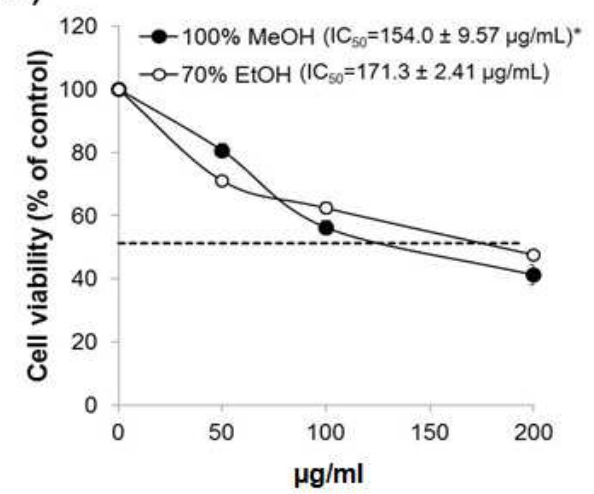

immemorial. They maintain the health and vitality of individuals and also cure diseases, including cancer without causing toxicity. More than $50 \%$ of all modern drugs in clinical use are of natural products, many of which have the ability to control cancer cells [24]. Medicinal plants are therefore being investigated for their anticancer properties, and the demand for natural anticancer agents increasing.

B)

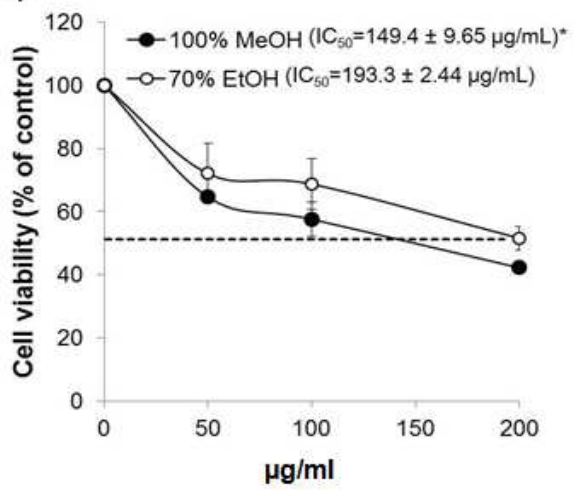

Fig. 2: The percentage of viable HCT116 and HepG2 cells after Camellia mistletoe ( $K$. japonica) treatment, Cell viability was determined by MTT assay after treatment with $0,50,100$ and $200 \mu \mathrm{g} / \mathrm{ml}$ of methanol and ethanol extracts for $72 \mathrm{~h}$, Each point is the mean \pm SD of three experiments, ${ }^{*} p<0.05$ compared toethanol extract of Camellia mistletoe

A)

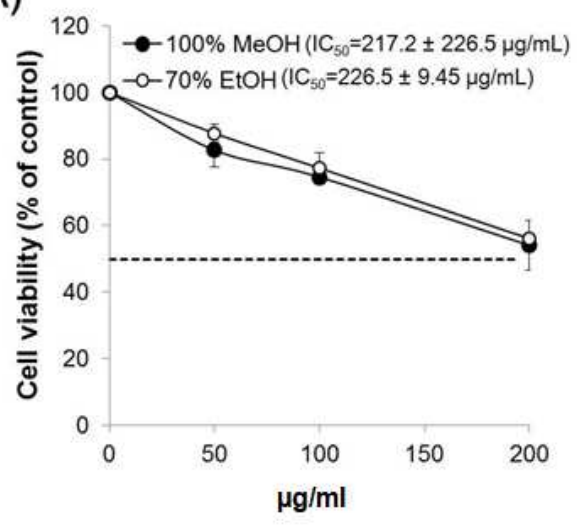

B)

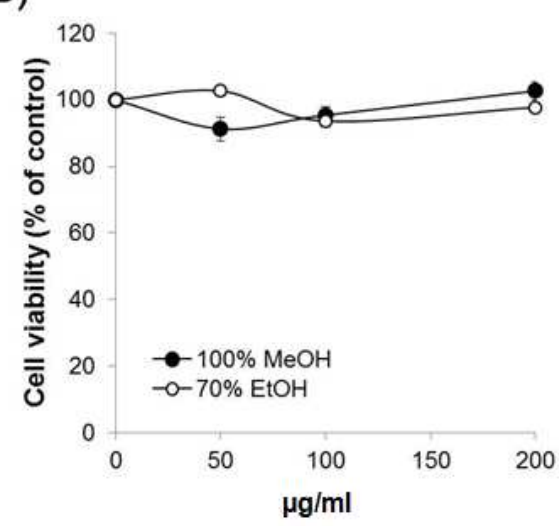

Fig. 3: The percentage of viable A549 and TK6 cells after Camellia mistletoe (K. japonica) treatment, Cell viability was determined by MTT assay after treatment with $0,50,100$ and $200 \mu \mathrm{g} / \mathrm{ml}$ of methanol and ethanol extracts for $72 \mathrm{~h}$, Each point is the mean \pm SD of three experiments, ${ }^{*} p<0.05$ compared to ethanol extract of Camellia mistletoe 
In the present study, human cervical cancer (Hela), malignant melanoma (A375), colon cancer (HCT 116), liver cancer (HepG2) and non-small cell lung adenocarcinoma (A549) cells were treated with various concentrations $(0-200 \mu 0 / \mathrm{ml})$ of Camellia mistletoe extracts for $72 \mathrm{~h}$, and then analyzed by MTT assay for the cell viability (\% control), as shown in fig. 1-3. Overall, both methanol and ethanol extracts of Camellia mistletoe were found to exhibits significantly growth inhibitory effect in all human cancer cell lines, and methanol extract was more active than ethanol extract $(p<0.05)$ (fig. 1-3). The highest cytotoxic activity ( $\mathrm{IC}_{50}$ of $64.6 \mu \mathrm{o} / \mathrm{ml}$ ) was obtained against the Hela cell line by the methanol extract of Camellia mistletoe (fig. 1), and the rank order of potency of the methanol and ethanol extracts of Camellia mistletoe for cell line was A375 (IC 50 of 135.6 and $156.3 \mu \mathrm{o} / \mathrm{ml}$ ), HCT116 (IC 50 of 154.0 and 171.3 $\mu \mathrm{g} / \mathrm{ml}$ ), HepG2 (IC 50 of 149.4 and $193.3 \mu \mathrm{o} / \mathrm{ml}$ ), A549 (IC $\mathrm{I}_{50}$ of 217.2 and $226.5 \mu \mathrm{o} / \mathrm{ml}$ ), respectively (fig. 1-3). Based on the results obtained, Camellia mistletoe extracts were effective in inhibiting all tested cancer cell proliferation. For the development of anticancer agents from natural products, it is important not only to screen the selectivity (or specificity) of the natural products among several cancer cells but also to assay if natural products exhibited any cytotoxicity in non-cancer cells. Thus, the effect of Camellia mistletoe extracts on non-cancer cells (human fibroblast TK6 cells) was tested. The TK6 cells did not exhibit cytotoxic effect with any extracts (fig.3B). One drawback of cytotoxic drug therapy for treatment of malignant diseases is serious toxicity. The data described above suggested that these Camellia mistletoe extracts are expected to be candidates for a non-toxic antitumor agent

\section{CONCLUSION}

Our study proposed Camellia mistletoe as a candidate for natural lipase inhibitor and anticancer agent. These in vitro antilipase and antiproliferative activities of Camellia mistletoe extracts seems to be closely correlated with its lectin contents or phenolic components. Further study is also needed to investigate the mechanism of antilipase and antiproliferative activities of Camellia mistletoe extracts.

\section{AUTHORS CONTRIBUTION}

Design, experimental part of the work and writing of the manuscript was done by the corresponding author Dr. M. Y. Kim.

\section{CONFLICT OF INTERESTS}

We declare that there is no conflict of interest

\section{REFERENCES}

1. Sawarkar HA, Singh MK, Pandey AK, Biswas D. In vitro anthelmintic activity of Ficusbengalhensis, Ficuscariaand Ficusreligiosa. A comparative anthelmintic activity. Int J Pharm Tech Res 2011;3:152-3.

2. Zuber D. Biological flora of central Europe: Viscum album L. Flora 2004;199:181-203.

3. Ishizu T, Winarno H, Tsujno E, Morita T, Shibuya H. Indonesian Medicinal Plants. XXIV. Stereochemical structure of Perseitol$\mathrm{K}^{+}$complex isolated from the leaves of Scurrulafusca (Loranthaceae). Chem Pharm Bull 2002;50:489-92.

4. Kim MK, Yun KJ, Lim DH, Kim JJ, Jang YP. Anti-inflammatory properties of flavone di- $C$-glycosides as active principles of camelliamistletoe, Korthalsella japonica. Biomol Ther 2016;19:1-8.

5. Osadebe PO, Okide GB, Akabogu IC. Study on anti-diabetic activities of crude methanolic extracts of Loranthusmicranthus (Linn.) sourced from five different host trees. J Ethnopharmacol 2004;95:133-8.

6. Kang DH, Park EM, Kim JH, Yang JW, Kim JH, Kim MY. Bioactive compounds and antioxidant activity of Jejucamellia mistletoe (Korthalsella japonica Engl.). J Life Sci 2016;26:1074-81.
7. Kang DH, Kim MY. Antimicrobial activity of Korean camellia mistletoe (Korthalsella japonica (Thunb.) Engl.) extracts. J Appl Pharm Sci 2016;6:226-30.

8. Hajt T, Hostanska K, Berki T, PT PT L, Boldizsdi F, NF Nz P. Oncopharmacological perspectives of a plant lectin (Viscum album Agglutinin-I): an overview of recent results from in vitro experiments and in vivo animal models, and their possible relevance for clinical applications. J Evidence-Based Complementary Altern Med 2005;2:59-67.

9. Dechakhamphu A, Wongchum N. Screening for anti-pancreatic lipase properties of 28 traditional Thai medicinal herbs. Asian Pac J Trop Biomed 2015;5:1042-5.

10. Kawaguchi K, Mizuno T, Aida K, Uchino K. Hesperidin as an inhibitor of lipases from porcine pancreas and Pseudomonas. Biosci Biotech Biochem 1997;61:102-4.

11. Park KM, Kwon KM, Lee SH. Evaluation of the antioxidant activities and tyrosinase inhibitory property from mycelium culture extracts. J Evidence-Based Complementary Altern Med 2015;1-7. http://dx.doi.org/10.1155/2015/616298

12. Malik M, Kanwal N, Hussain A. Role of community pharmacist and nutritionists in obesity management: a literature review. Asian J Pharm Clin Res 2017;10:40-2.

13. WHO. Obesity and Overweight. Geneva, Switzerland: World Health Organization; 2003.

14. James WPT, Caterson ID, Coutinho W, Finer N, Van Gaal LF, Maggioni AP, et al. Effect of sibutramine on cardiovascular outcomes in overweight and obese subjects. N Engl J Med 2010;363:905-17.

15. Bray GA, Greenway FL. Current and potential drugs for the treatment of obesity. Endocr Rev 1999;20:805-75.

16. Yun JW. Possible anti-obesity therapeutics from the nature-a review. Phytochemistry 2010;71:1625-41.

17. Kim GN, Shin MR, Shin SH, Lee AR, Lee JY, Seo BI, et al. Study of antiobesity effect through inhibition of pancreatic lipase activity of Diospyros kaki fruit and Citrus unshiu peel. Biomed Res Int 2016;1-7. http://dx.doi.org/10.1155/2016/1723042

18. Conforti F, Perri V, Menichini F, Marrelli M, Uzunov D, Statti GA, Menichini F. Wild mediterranean dietary plants as inhibitors of pancreatic lipase. Phytother Res 2012;26:600-4.

19. Sanchez-Ferrer A, Rodrygez-Lopez JN, Garcya-Carmona F. Tyrosinase: a comprehensive review of its mechanism. Biochem Biophys Acta 1995;1247:1-11.

20. Chang TS. An updated review of tyrosinase inhibitors. Int J Mol Sci 2009;10:2440-75.

21. Uchida R, Ishikawa S, Tomoda H. Inhibition of tyrosinase activity and melanin pigmentation by 2-hydroxytyrosol. Acta Pharm Sin B 2014:4:141-5

22. Ruksiriwanich W, Sringarm K, Jantrawut P. Stability enhancement of Celastruspaniculatusseed oil by loading in niosomes. Asian J Pharm Clin Res 2014;7:186-91.

23. Lee KK, Kim MK, Song YS, Lee M. The composition of phenolic acids and flavonoids, and beauty cosmetic biological activities of Korean mistletoe(Viscum album) extracts. Int J BioSci Biotech 2013;5:175-82.

24. Rosangkima G, Prasad SB. Antitumour activity of some plants from Meghalaya and Mizoram against murine ascites. Doltonity Some Indian J Exp Biol 2004;42:981-8.

\section{How to cite this article}

- $\quad$ Min Young Kim. Inhibitory activities of Camellia mistletoe (K. japonica) extracts on pancreatic lipase, tyrosinase and cancer cell proliferation. Int J Pharm Pharm Sci 2017;9(10):187-190. 